\title{
TREN HIJRAH DAN ISU RADIKALISME DALAM MENINGKATKAN KUALITAS MASYARAKAT ISLAM
}

\author{
Musa \\ IAIN Syaikh Abdurrahman Siddik Bangka Belitung \\ musaradit@gmail.com
}

\begin{abstract}
Abstrak
The trend of appearance changes experienced by some Muslims in Indonesia is called the hijrah. The term hijrah itself actually has the meaning of moving. The move in question is the transfer of the Prophet Muhammad sallallaahu 'alayhi wa sallam from Mecca to Medina because of the threat from the Quraysh tribe who opposed the Prophet's preaching calling for monotheism. But now the term hijrah is pinned to the movement of a person's change from being initially bad to getting better. For now, hijrah has a different form, which is identical to repent and look like using the robe, veil, for men to grow beards and so on. In this era, the trend of migration can easily be found in various circles of millennial. There are various factors that influence their hijrah actions, including being invited by friends, breaking up love, experiencing sad events, being aware of death and so on. This hijrah trend utilizes social media as a means of da'wah, friendship between Muslims and disseminating advisory posts. The issue of radicalism that arises which is pinned to those who emigrate is not true because emigration is an attempt by someone to get closer to the almighty Allah. Even if there is radicalism, it is the work of irresponsible people who act on behalf of certain parties.

Keywords: Hijrah Trends, Radicalism, Islamic Society
\end{abstract}

\begin{abstract}
Abstrak
Tren perubahan penampilan yang dialami oleh sebagian umat Islam di Indonesia disebut dengan hijrah. Istilah hijrah sendiri sebenarnya memiliki arti bergerak. Langkah yang dimaksud adalah pemindahan Nabi Muhammad sallallaahu 'alayhi wa sallam dari Mekah ke Madinah karena ancaman dari suku Quraish yang menentang dakwah Nabi yang menyerukan monoteisme. Tapi sekarang istilah hijrah disematkan pada pergerakan perubahan seseorang dari semula buruk menjadi lebih baik. Untuk saat ini, hijrah memiliki bentuk yang berbeda, yang identik dengan bertobat dan terlihat seperti menggunakan jubah, kerudung, bagi pria untuk menumbuhkan janggut dan sebagainya. Di era ini, tren migrasi dapat dengan mudah ditemukan di berbagai kalangan milenial. Ada berbagai faktor yang memengaruhi tindakan hijrah mereka, termasuk diundang oleh teman-teman, putus cinta, mengalami peristiwa menyedihkan, menyadari kematian dan sebagainya. Tren hijrah ini memanfaatkan media sosial sebagai sarana dakwah, pertemanan antara
\end{abstract}


Muslim dan penyebaran pos-pos penasehat. Masalah radikalisme yang muncul yang disematkan kepada mereka yang beremigrasi tidak benar karena emigrasi adalah upaya seseorang untuk mendekatkan diri kepada Allah SWT. Sekalipun ada radikalisme, itu adalah pekerjaan orang-orang yang tidak bertanggung jawab yang bertindak atas nama pihak-pihak tertentu.

Kata kunci: Tren Hijrah, Radikalisme, Masyarakat Islam

\section{PENDAHULUAN}

Masyarakat Islam adalah masyarakat yang berusaha selalu selalu mendekatkan diri kepada yang kuasa Allah Swt dimanapun berada. Asas yang paling utama yang tegak dalam masyarakat adalah aqidah, khususnya aqidah islam. Maka tugas masyarakat yang pertama, yaitu memelihara, menjaga, dan memperkuat aqidahnya agar tidak mudah goyah dan terpengaruh saat menghadapi kehidupan diera globalisasi yang penuh dengan hasutan dan ancaman oleh orang-orang yang ingin menghancurkan agama Islam. Semakin kuat akan aqidah seseorang akan menumbuhkan rasa cinta pada Rabbnya karena ia akan menyadari bahwa pencipta alam semestesta ini adalah yang maha pencipta yaitu Allah SWT sehingga akan mengarahkan pikirannya kepada Allah SWT yang wajib dan satu-satunya disembah karena tidak ada kekutu bagiNya.

Asas kedua yang dapat dijadikan sebagai tolak ukur masyarakat Islam yaitu pada akhlaknya. Manusia diberikan potensi kebaikan dan keburukan sejak lahir ke dunia. Sebagaimana firman Allah SWT Surah Ass-Syam ayat 7-8 yang berbunyi;

Artinya;

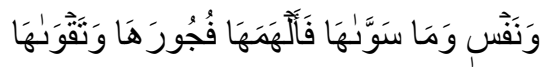

Dan jiwa serta penyempurnaannya, maka Allah mengilhamkan kepadanya (jalan) kefasihan dan ketaqwaan.

Manusia dengan ketaqwaannya tersebut dapat dikembangkan melalui pengajaran dari kitab suci, khusunya Al-qur'an yang menjadi 
pedoman hidup bagi umat manusia. Bagi siapa saja yang membaca dan mengamalkan ajarannya maka akan terpancar akhlaknya.

Masyarakat Islam bukanlah masyarakat yang diliputi perasaan dendam atau dengki terhadap sesamanya, melainkan menjadi masyarakat yang yang memiliki rasa cinta terhadap sesame dan cinta terhadap penciptanya. Masyarakat Islam yang lebih mengutamakan persaudaraan Islam atau disebut dengan Ukhuwah Islamiyah. Semua dilakukan agar tercapainya sebuah masyarakat Islami yang kuat aqidahnya serta baik pula akhlaknya.

Akhir-akhir ini banyak dijumpai wanita yang menggunakan cadar, hijab yang panjang dan lebar, sedangkan di kalangan pria juga menggunakan celana cingkrang, baju jubah serta memelihara jenggot. Penampilan tersebut yang dulu hanya berlaku di kalangan kampung Arab, kini mulai digunakan oleh orang-orang yang bukan termasuk dalam komunitas Arab. Apa yang terjadi di sebagian masyarakat Islam di Indonesia kini tidak lepas dari semakin gencarnya dakwah yang bertemakan purifikasi agama serta kembali kepada sumber agama Islam yaitu Al-Qur'an.

Tren perubahan penampilan yang dialami oleh sebagian umat Islam di Indonesia ini disebut dengan istilah hijrah. Istilah hijrah sendiri sendiri sebenarnya memiliki arti berpindah. Berpindah yang dimaksud adalah perpindahan Nabi Muhammad shalallahu 'alaihi wa sallam dari Mekah ke Madinah karena adanya ancaman dari suku Quraisy yang menentang dakwah Nabi yang menyerukan kepada ketauhidan. ${ }^{1}$

Tetapi kini istilah hijrah disematkan kepada gerakan perubahan seseorang dari yang awalnya buruk kemudian menjadi lebih baik. ${ }^{2}$ Penyematan istilah hijrah sendiri sebenarnya secara langsung berkaitan

\footnotetext{
${ }^{1}$ Hamka, "Hijrah dalam Perspektif Sosio-Kultural Historis”, Hunafa, Vol. 2, No. 2, Agustus 2005, h. 120.

2 Erik Setiawan dkk., "Makna Hijrah pada Mahasiswa Fikom Unisba di Komunitas ('followers') Akun 'LINE@DakwahIslam'”, Jurnal MediaTor, Vol. 10, No. 1, Juni 2017, h. 101.
} 
dengan perubahan sikap dan penampilan para artis di Indonesia sekarang. Dimana dapat memberikan tanda kutip terhadap istilah hijrah yang berarti perubahan seseorang dari yang buruk menuju yang baik. Tercatat ada beberapa artis yang mengalami hijrah yaitu seperti Teuku Wisnu, Shireen Sungkar, Sakti Ari Seno (gitaris band Sheila On 7) yang kini berganti nama menjadi Salman al-Jugjawy, Arie Untung dan sebagainya.

Dengan maraknya tren hijrah yang dilakukan oleh banyak orang, maka bisa dikatakan meningkatnya kualitas masyarakat Islam. Karena semakin taatnya seseorang, maka semakin baik pula prilaku dan pemikirannya. Oleh karena itu, berangkat dari paparan di atas, tren hijrah yang terjadi pada masa sekarang ini tidak lepas dari keinginan seseorang untuk meningkatkan kualitas keimanan seseorang. Oleh karena itu, penulis ingin mengangkat permasalahn ini dengan tema "Tren Hijrah dan Isu Radikalisme dalam meningkatkan kualitas Masyarakat Islam.

\section{PEMBAHASAN}

\section{A. TREN HIJRAH}

\section{Pengertian Hijrah}

Hijrah berasal dari kata hajara-yahjuru-hajaran yang berarti memutuskan hubungan serta meninggalkan. ${ }^{3}$ Dalam pendapat lain, hijrah yang berasal dari هجر- يـ هجر- هجرا - هجراذا - اهجره yang bearti memutuskan hubungan dengan dia. Menurut al-Qurthubi, al-hijrah berasal dari kata hajara, hajran wa hujranan yang merupakan lawan kata dari al-wasal yang berarti bersambung. Bentuk isim-nya yaitu al-hijrah. ${ }^{4}$ Menurut al-Raghib alAsfahani, kata hijrah memiliki arti seseorang yang meninggalkan, baik secara fisik maupun

3 A.W. Munawwir, Kamus Al-Munawwir Arab-Indonesia Terlengkap, (Surabaya: Pustaka Progresif, 1984), 482

4 Suarni, “Sejarah Hijrah dalam Perspektif Al-Qur'an”, Jurnal Al-Mu'ashirah, Vol. 13, No. 2, Juli 2016, 145. 
perkataan serta hati. ${ }^{5}$ Menurut kamus bahasa indonesia kata tren mempunyai makna gaya mutakhir.

Kemudian kata hijrah dalam al-Quran diartikan sebagai berpindah, karena dalam konteks sejarah hijrah menjelaskan mengenai proses perpindahan Nabi Muhammad dan para pengikutnya dari Mekah ke Madinah untuk menghindari tekanan kafir Quraisy pada tahun $662 \mathrm{M}^{6}$. Namun dalam perkembangannya makna kata hijrah harus diperluas oleh kelompok-kelompok islamis sebagai tindakan untuk meninggalkan perbuatan yang yang tidak islami menjadi lebih Islami.

Setidaknya kata hijrah memiliki lima makna yang berkaitan dengan peristiwa hijrah nabi, yaitu: ${ }^{7}$

a) Hijrah sebagai strategi perjuangan Nabi. Hal ini bisa dilihat dari cara Nabi membangun kekuatan dan pondasi umat Islam dari dasar, yaitu Masjid Quba. Karena masjid merupakan tempat ibadah serta berkumpul. Strategi tersebut menunjukkan bahwa penerapan Islam tidak hanya dalam aspek ibadah, tetapi juga dalam hal ekonomi, permasalahan sosial dan sebagainya.

Penegasan identitas umat Islam. Peristiwa hijrah Nabi tersebut merupakan ujian bagi umat Islam untuk dapat menegaskan identitas keimanannya. Karena di Mekah mendapatkan perlawanan dari kaum kafir Quraisy, dengan adanya hijrah menuju Madinah tersebut menjadikan umat Islam bisa lebih berani menegaskan identitas mereka. Karena di Madinah Nabi membangun masyarakat Islam secara kaffah atau keseluruhan.

${ }^{5}$ Ahzami Samiun Jazuli, Hijrah dalam Pandangan al-Qur'an, (Jakarta: Gema Insani, 2006), 16.

6 Afina Amna, 'HIJRAH ARTIS SEBAGAI KOMODIFIKASI AGAMA', Jurnal Sosiologi Reflektif, 13.2 (2019), 331-50.

${ }^{7}$ Suarni, "Sejarah Hijrah dalam Perspektif Al-Qur'an”, Jurnal Al-Mu'ashirah, Vol. 13, No. 2, Juli 2016, h. 145 
b) Membangun Peradaban. Dengan hijrahnya Nabi beserta umatnya menuju Madinah memiliki makna membangun peradaban Islam. Maka Nabi membangun tiga orientasi umat, yaitu orientasi budaya, kerja dan kapital. Ketiga orientasi tersebut merupakan masalah yang penting bagi umat Islam hingga saat ini.

c) Konsep persatuan. Dengan adanya peristiwa hijrah menunjukkan bahwa persatuan sebagai sesama Muslim adalah hal yang sangat penting. Selain itu, dengan adanya Piagam Madinah menunjukkan bahwa Nabi juga mengatur kehidupan masyarakat yang terdiri dari berbagai agama pada saat tersebut.

d) Konsep masyarakat egalitarian. Peristiwa hijrah tersebut menunjukkan adanya sikap masyarakat yang egaliter (penuh kebersamaan). Hal ini ditunjukkan saat Abu Bakar bersedih di Gua Tsur kemudian Nabi menenangkannya. Tetapi kemudian saat perang Badar, Nabi gelisah dan terus berdoa, kemudian Abu Bakar menenangkan Nabi.

\section{Bentuk-bentuk Hijrah}

Bentuk-bentuk hijrah di antaranya adalah hijrah makaniyah, hijrah nafsiyah dan hijrah amaliyah. ${ }^{8}$ Hijrah makaniyah adalah pindah dari tempat yang tidak aman menuju tempat yang lebih aman. Hijrah ini seperti yang dilakukan oleh Nabi Muhammad dari Makkah menuju Madinah karena tindakan represif kaum kafir Quraisy terhadap dakwah tauhid dan kaum muslim. Tetapi tidak semuanya mendapatkan tindakan represif dari kaum kafir Quraisy seperti sahabat Abu Bakr dan 'Umar, tetapi mereka semuanya

8 Busthomi Ibrohim, "Memaknai Momentum Hijrah", Studia Didkatika Jurnal Ilmiah Pendidikan, Vol. 10, No. 2, Tahun 2016, h. 65. 
tetap diperintahkan untuk berhijrah untuk menguji keimanan mereka, seperti yang terdapat dalam al-Qur'an:

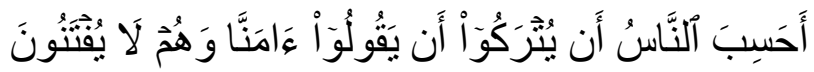

Yang artinya;

Apakah manusia mengira bahwa mereka akan dibiarkan hanya dengan mengatakan, "kami telah beriman", dan mereka tidak diuji?" (al-Ankabut ayat 2)

Selanjutnya yaitu hijrah nafsiyah atau perindahan secara keseluruhan dari kekafiran menuju kepada keimanan. Hijrah jenis ini banyak dilakukan oleh orang-orang yang telah mendapatkan hidayah seperti melalui mempelajari Islam, mengetahui ahlak umat Islam yang baik dan sebagainya. Jenis hijrah yang terakhir yaitu hijrah amaliyah yang berarti perpindahan perilaku dari perilaku jahiliyah, perilaku yang jauh dari agama menuju kepada perilaku yang diperbolehkan dalam Islam. Hijrah amaliyah ini juga berarti meninggalkan segala yang dilarang oleh Allah dan Nabi Muhammad menuju kepada perilaku yang diridai-Nya.

Ada sebagian ulama yang menambahkan jenis-jenis hijrah yaitu hijrah maknawiyah. Hijrah maknawiyah sendiri terbagi menjadi empat, yaitu hijrah i'tiqadiyah, hijrah fikriyah, hijrah syu'uriyah dan hijrah sulukiyah. Hijrah i'tiqadiyah merupakan hijrah keyakinan. Karena iman seseorang bersifat naik turun, terkadang iman seseorang kuat dan juga terkadang lemah, bahkan bisa mendekati kepada kekufuran. Maka untuk menghindari kekufuran tersebut setiap orang harus bisa segera melakukan hijrah i'tiqadiyah agar terhindar dari lemahnya iman.

Selanjutnya yaitu hijrah fikriyah yang berarti hijrah pemikiran. Hijrah pemikiran ini dilakukan agar setiap orang terhindar dari pemikiran-pemikiran yang melemahkan iman, pemikiran yang melemahkan keyakinan iman seseorang. Karena 
bisa jadi seseorang tersebut tidak sadar telah mengikuti kebiasaankebiasaan yang bisa jadi menjerumuskan kedalam kekufuran. Selanjutnya yaitu hijrah syu'uriyah, yang berarti hijrah dari kesenangan. Bisa jadi seseorang terpengaruh oleh hiburan-hiburan, musik, pakaian, bacaan yang melalaikan. Maka hijrah syu'uriyah dilakukan untuk menghindari hal-hal tersebut. Dan yang terakhir yaitu hijrah sulukiyah. Suluk berarti tingkah laku atau akhlak. Akhlak manusia tidak bisa terlepas dari pergeseran nilai, sehingga menimbulkan akhlak yang buruk. Maka hijrah dilakukan untuk menghindari akhlak yang tercela tersebut. ${ }^{9}$

Untuk saat ini, hijrah memiliki bentuk yang berbeda, yaitu identik dengan bertobat dan berpenampilan seperti menggunakan gamis, cadar, untuk pria menumbuhkan jenggot dan sebagainya. Pada era sekarang ini, tren hijrah bisa dengan mudah ditemui di berbagai kalangan kaum milenial. Ada berbagai faktor yang mempengaruhi tindakan hijrah mereka, di antaranya adalah diajak oleh teman, putus cinta, mengalami peristiwa yang menyedihkan, sadar akan kematian dan sebagainya. Tren hijrah ini memanfaatkan media sosial sebagai sarana dakwah, silaturahmi antara umat Islam dan menyebarkan postingan-postingan nasehat.

Dalam era milenial kini, makna hijrah adalah berpindah dari kehidupan lama, kebiasaan lama yang buruk, yang jauh dari agama menuju kepada kehidupan baru yang lebih baik. Dikarenakan pergaulan yang mengarah kepada hal-hal negatif, maka dengan berhijrah merupakan solusi untuk menghindari hal-hal yang negatif dan tidak bermanfaat tersebut.

${ }^{9}$ Anonim, "Makna Hijrah",

http://lsipk.unisba.ac.id/index.php/component/content/article/97-hijrah/117(diakses 28 November 2019) 
Dilihat dari sudut pandang sosial, fenomena perempuanperempuan yang memutuskan untuk menggunakan cadar ${ }^{10} /$ niqab menimbulkan bebagai pertanyaan, bahkan tak sedikit muncul praduga tak berdasar dalam bentuk stigma yang mebuat perempuan bercadar itu terintimidasi dilingkungan yang beragam ini. ${ }^{11}$

Sebagaimana yang telah disampaikan menteri agama RI tentang larangan menggunakan cadar dan celana cingrang bagi ASN ketika sedang bertugas, beliau mempersilahkan ASN menggunakan celana cingrang jika sedang di rumah atau di luar urusan kedinasan. ${ }^{12}$

\section{B. RADIKALISME DAN FAKTOR-FAKTOR PENYEBAB PERKEMBANGNYA}

\section{Pengertian Radikalisme}

Secara etimologi, istilah radikalisme berasal dari bahasa latin radix yang artinya akar, pangkal dan bagian bawah, atau bisa juga menyeluruh, habs-habisan dan amat keras untuk menuntut perubahan. Sedangkan secara terminologi radikalisme adalah aliran atau faham yang radikal terhadap tatanan politik, paham

10 Makna cadar dapat dibedakan dalam tiga makna sebagai mana menurut Nurul Istika pada tulisannya yang berjudul Tindakan Sosial dan Religuisitas Perempuan Bercadar (Studi Di Surabaya, Gersik, dan Lamongan, Provinsi Jawa Timur).

http://repository.unair.ac.id/87327/5/JURNAL\%20\%28Nurul\%20Istika071511433050\%2 9.pdf, (diakses 14 November 2019, 23.15 wib). Pertama makna fisik yakni mengenakan cadar pada pengharapan penampilan, seperti pengharapan untuk terlihat lebih anggun atau lebih syar"i. Makna tersebut dimiliki oleh aktor perempuan muslim muda yang secara emosioal masih mendapat pengaruh lingkungan. Kedua, makna non fisik yakni mengenakan cadar pada pengharapan untuk melakukan transisi dari masa lalu yang hendak ditinggalkan, seperti untuk membut identitas baru (hijrah). Makna tersebut dimiliki oleh aktor dari latar belakang yang bertentangan dengan nilai agama. Ketiga, makna agama yakni mengenakan cadar pada pengharapan menjalankan ketaatan beragama. Makna tersebut dimiliki oleh aktor perempuan dewasa atau yang kekhawatirannya terkait respon sosial terabaikan oleh dominasi tujuan tertinggi ketaatan pada Sang Pencipta.

11 Lintang Ratri, Cadar, Media, dan Identitas Perempuan Muslim Vol 39, No 2 (2011), dikutip Nurul Istika, (diakses 14 November 2019, 23.15 WIB)

12 https://www.merdeka.com/peristiwa/ucapan-menteri-agama-fachrul-razi-yangjadi-kontroversi-dan-sentilan-dpr.html (diakses 14 November 2019, 23.30 wib) 
atau aliran yang menuntuk perubahan social dan politik dalam suatu Negara secara kesar ${ }^{13}$. Sedangkan dalam bahasa Arab, radikalisme disebut al-tharaf atau puncak dari dari sesuatu dan bisa juga berarti pinggir. Diperjelas lagi oleh Yusuf al-Qardhawi memahami al-Tatharruf, yang berarti berada di pinggir, jauh dari tempat yang berada di tengah ${ }^{14}$.

Disamping itu Simon Tormey dalam International Enyclo[edia of Social Sciences (Vol. 7, hal, 48), radikalisme merupakan sebuah konsep yang bersifat kontekstual dan posisional, dalam hal ini kehadirannya merupakan antithesis dari ortodoks atau arus utama (mainstream), baik bersifat social, sekuler, saintifik, maupun keagamaan. Menurutnya, radikalisme tidak mengandung seperangkat gagasan dan argument, melainkan lebih memuat posisi dan ediologi yang mempersoalkan atau menggugat sesuatu (atau segala sesuatu) yang dianggap mapan, diterima, atau menjadi pandangan umum. ${ }^{15}$

Kelompok Islam radikal adalah sebuah gerakan politik ekstrim yang berusaha membentuk Negara Islam melalui perjuangan bersenjata. Dimana terdapat doktrin-doktrin pada kelompok untuk membenarkan tindakan kekerasan untuk menghilangkan rezim di dunia yang dianggap kafir saat ini. Tindakan kekerasan inilah, maka gerakan Islam radikal sering dicap sebagai teroris oleh Negara-negara barat khususnya Amerika.

\footnotetext{
${ }^{13}$ Eka Yani Arfina, Kamus Lengkap Bahasa Indonesia dilengkapi dengan EYD dan Singkatan Umum, Surabaya; Tiga Dua.t.th.

${ }^{14}$ Mustafa Luthfi, Melenyapkan Hantu Terorisme: Dari Dakwah Kontemporer, (Jakarta Timur: Pustaka al-Kautsar, 2008), hlm. 224

15 Muhammad Najib, Yang Musa, Yang Radikal: Refleksi Sosiologis Terhadap Fenomena Radikalisme Kum Muda Muslim di Indonesia Pasca Orde Baru. Jurnal Maarif, Vol. 8, No. I Juli 2013): 14-41. Diakses dari http://maarifinstitute.org/images/xplod/jurnal/vol\%20viii\%.pdf tanggal 23 November 2019.
} 
Radikalisasi juga merupakan proses perubahan dimana kelompok mengalami transformasi ideologi atau perilaku yang mengarah pada penolakan prinsip-prinsip demokrasi dengan cara menuntut untuk dilakukannya revolusi di bidang social politik, social ekonomi, dan perubahan budaya dengan jalan kekerasan atau peningkatan tingkat kekerasan dengan cara memperluas pemilihan target yaitu memasukkan warga sipil dalam aksi bom bunuh diri.

\section{Faktor-Faktor Penyebab Lahirnya Radikalisme}

Pesoalan radikalisme tidak boleh dipandang hanya dari sudut internal agama saja, tetapi memerlukan kajian literature yang mendalam untuk mengetahui faktor-faktor penyebab kemunculannya. Radikalisme tidaklah terjadi dalam situasi vakum tetapi memiliki keterkaitan dengan situasi makro baik yang berkaitan dengan masalah social-ekonomi maupun dengan masalah politik.

Dalam pandangan Murthadha Muthahari16, banyaknya gerakan-gerakan radikalisme keagamaan yang akhir-akhir ini muncul karena adanya beberapa factor yang menjadi salah satu penyebab antara lain:

Pertama, Faktor norma dan ajaran. Ajaran yang ada mempengaruhi tingkah laku dan tindakan seorang muslim yang berasal al-Qur'an dan Hadits serta bisa juga ijma' ulama. Ajaran ini diinterpretasikan dan diinternalisasikan. Karena ajaran yang ada sangat umum, hal ini memungkinkan munculnya beberapa interpretasi. Hal ini juga dimungkinkan karena setiap anggota masyarakat muslim mengalami sosialisasi primer yag berbeda, disamping pengalama pendidikan dan tingkatan ekonomi mereka 
juga tidak sama. Dari hasil interpretasi ini memunculkan apa yang diidealkan berkaitan dengan kehidupan masyarakat islam.

Kedua, factor sikap pemahaman mengenai penerapan syariat Islam, bentuk Negara Islam Indonesia dan khilafah Islamiyah. Sikap ini adalah kelanjutan dari penafsiran terhadap ajaran agama Islam. Diasumsikan bahwa ada beberapa sikap umum yang muncul setelah masyarakat menafsirkan ajaran Islam. Sikap ini tersimbolkan dalam penerapan pemahaman muslim terhadap ajaran agama mereka. Dalam hal ini ada tiga golongan yakni sekuler (nisbi), subtansialis dan skriptualis.

Ketiga, factor kondisi social dalam masyarakat. Hal ini termasuk di dalamnya adalah factor-faktor domistik dan internasional. Hegemoni politik ole Negara akan represi yang dilakukan oleh kelompok apapun terhadap umat Islam akan melahirkan respon yang berbeda dari berbagai kelompok yang ada. Kalangan sekuler sama sekali tidak merespon hal tersebut. Hanya kelompok skriptualis yang diasumsikan akan memperlihatkan sikap radikal. Kelompok substansialis meskipun punya kepedulian terhadap Islam dan juga umatnya dalam berbagai bidang, akan memperlihatkan seikap moderat. Misalnya mereka akan kelihatan luwes baik mengenai Negara Islam atau khalifah Islamiyah maupun mengenai (formalisasi) penerapan syariat Islam.

Selanjutnya, dalam pandangan Tarmizi Taher ${ }^{17}$ disebutkan secara umum ada tiga kecenderungan yang menjadi indikasi radikalisme.

1) Radikalisme merupakan respon terhadap kondisi yang sedang berlangsung, biasanya respon tersebut muncul dalam bentuk evaluasi, penolakan atau bahkan perlawanan. Masalah-masalah

17 Tarmizi Taher, dkk., Radikalisme Agama, (Jakarta: PPIM IAIN Jakarta, 1998), h. xvi 
yang ditolak dapat berupa asumsi, ide, lembaga atau nilai-nilai yang dipandang bertanggung jawab terhadap keberlagsungan kondisi yang ditolak.

2) Radikalisme tidak berhenti pada upaya penolakan, melainkan terus berupaya mengganti tatanan tersebut dengan bentuk tatanan lain. Cirri ini menunjukkan bahwa di dalam radikalisme terkandung suatu program atau pandangan dunia tersendiri. Kaum radikalis berupaya kuat untuk menjadikan tatanan tersebut sebagai ganti dari tatanan yang ada. Dengan demikian, sesuai dengan arti kata "radic", sikap radikal mengandaikan keinginan untuk mengubah keadaan secara mendasar.

3) Kuatnya keyakinan kaum radikalis akan kebenaran program atau ideologi yang merekabawa. Sikap ini pada saat yang sama dibarengi dengan penafian kebenaran system lain yang akan diganti dalam gerakan social, keyakinan tentang kebenaran program atau filosofi sering dikombinasikan dengan cara-cara pencapaian yang mengatasnamakan nilai-nilai ideal seperti kerakyatan atau kemanusiaan. Akan tetapi kuatnya keyakinan tersebut dapat mengakibatkan munculnya sikap emosional dikalangan kaum radikalis.

Memperhatikan ketiga penyebab terjadinya radikalisme agama atas nama "Islam", sebagaimana yang telah dipaparkan di atas, sesungguhnya tidak ditemukan dalil (hujjah) yang menyatakan bahwa Islam melegitimasi atau bahkan mengajarkan radikalisme kepada umatnya. Akan tetapi justeru radikalisme ini lahir karena adanya pemahaman yang keliru di dalam menafsirkan maksud agama itu sendiri, lalu diikuti dengan semangat untuk menerapkan syariat Islam secara struktural dan formalistik di negara Indonesia atau karena adanya indikasi hegemoni (intervensi) dunia internasional terhadap fenomena di dalam negeri. 
Pada hakekatnya semua orang berpeluang untuk radikal dan funadamental tanpa memandang agama tertentu, manakala antara hak dan kewajiban sebagai individu dan sebagai kelompok masyarakat terabaikan dan tidak dijamin sehingga radikalisme muncul dipengaruhi oleh hal yang sangat kompleks, bisa dari faktor ekonomi, ideologi, politik bahkan agama.

Radikalisme tidak sejalan dengan karakteristik Islam dan ajaran jalan "tengah" yang menjadi ciri khasnya, dan tidak sejauh dengan pemahaman benar al-Qur'an dan hadis dari salaf al-Shāleh. Intelektualitas radikalisme hanya akan menghasilkan kekerasan, kehancuran, kekacauan, dan bencana yang merupakan fitnah paling berbahaya. Menjadi kewajiban dari kontemporer untuk selalu mengingatkan kaum muslim tentang bahayanya sikap radikalisme tersebut khususnya pada saat dewasa ini ketika kekuatan Barat dan Timur secara serentak melontarkan tuduhan "agama radikal" dan "teroris" terhadap agama Islam dengan dukungan propaganda media massa zionisme international. Pada saat yang sama mereka sengaja menutup mata atas aksi radikalisme dan terorisme terjahat yang dilakukan Israel terhadap rakyat Palestina. ${ }^{18}$

Apabila seorang Muslim semakin jauh dari ajaran agamanya, maka ia akan merasa semakin aneh terhadap agamanya bahkan semakin memgingkarinya. Akhirnya menjurus kepada menuduh setiap saudaranya yang konsisten dengan ajaran agamanya sebagai radikal. Hal ini akan membantu kekuatan anti islam dalam melaksanakan misi mereka untuk menghancurkan Islam dan kaum Muslimin dari dalam sendiri. Yusuf al-Qardhawi lebih jauh mengingatkan, "Banyak kaum muslimin yang hidup di dunia Islam dengan memakai nama-nama Islam dengan intelektualitas Barat, mereka menganggap muslim yang konsisten melaksanakan ajaran

${ }^{18}$ Ibid. h. 226 
Allah dan menghindari larangannya sebagai radikalisme agama. Sebagian muslim yang sudah terbiasa dengan tradisi asing dan Barat, mereka melihat saudaranya yang berperilaku sesuai ajaran Islam dalam tata cara makan, minum, dan berpakaian, justru dianggap sangat radikal dan fanatik.

Sangat ironis memang jika radikalisme (fundamentalisme) agama dianggap sebagai sebuah gerakan jihad oleh orang atau kelompok radikal dalam menjalankan aksinya, sehingga ini adalah celah bagi Barat untuk menvonis bahwa Islam adalah teroris karena dalam Islam jihad adalah sebuah idiologi yang sifatnya subtantif.

Menurut survey yang dilakukan oleh Azyumardi Azra ${ }^{19}$, bahwa gerakan radikalisme Islam memiliki genealogi dengan gerakan Islam salafi yang berkembang di Timur Tengah, khususnya Arab Saudi. Entah suatu kebetulan atau memang seperti itu, kebanyakan tokohtokoh gerakan Islam radikal di Indonesia adalah "keturunan Arab". Seperti, Habieb Riziq Syihab yang memimpin Front Pembela Islam (FPI), Ja'far Umar Thalib memimpin Lasykar Jihad, Abu Bakar Ba'asyir memimpin Majelis Mujahidin Indonesia (MMI), Habieb Husein al-Habsyi memimpin Ikhwanul Muslimin, Hafidz Abdurahman memimpin Hizbut Tahrir Indonesia (HTI). Hampir sama dengan pendapat ini, Barton juga menyatakan bahwa akar radikalisme Islam tumbuh dan berkembang dari ide-ide Wahabi, NeoWahabi dan Hassan al-Banna. Dalam banyak hal radikalisme Islam di Indonesia juga dapat dikaitkan dengan Ibn Qayyim al-Jauzi yang memiliki kesamaan dalam hal penerapan syari'ah Islam di beberapa tahun terakhir.

Dari sini, ideologi radikal tampak begitu dekat dengan permainan kuasa. Menempuh jalur politik diyakini dapat

19 Rudi Pranata, An Indonesianist's View of Islamic Radicalism, (Jakarta: Koran Tempo, Pebruari, 15-21, 2005), h. 44. 
mengantarkan Islam pada kondisi lebih tinggi, yaitu, mimpi formalisasi syariat dan terbentuknya negara Tuhan. Sampai kini, kaum radikal terus berjuang untuk dua hal itu, baik melalui lobi-lobi politik maupun fundamental-ideologis. Ironisnya, Islam hanya dijadikan pendasaran politik kepentingan. Padahal, dalam praktiknya, teror, anarki dan kekerasan secara bergantian dilakukannya. Tidak ada batas baik-buruk, moral-amoral. Semuanya berjalan di tataran politik yang menjauh dari Islam. Akhirnya, radikalisme kadang keliru dalam memahami Islam.

Mungkin, di sinilah letak kekuatan radikalisme Islam Indonesia. Semakin melekat dalam setiap segmentasi sosial, semakin susah dibendung. Ia pandai membaca ruang sosial yang tak cepat lekang. Karena memahami setiap ruang akan mengantarkan radikalisme mencipta mentalitas kultural. Kelompok radikal dalam menjalankan aksinya, semakin ke sini tidak lagi bersifat sembunyisembunyi bahkan mereka telah berani secara terang-terangan. Lalu sasaran kaum radikal saat ini tidak hanya ditujukan kepada kelompok yang dikategorikan non muslim saja, akan tetapi mereka yang muslim pun tidak luput dari sasaran kaum radikal.

Namun demikian, dalam pandangan penulis apa pun yang melatar belakangi lahirnya radikalisme lebih tepat jika tindakan ini dikategorikan sebagai kejahatan (kriminal murni) yang tidak ada sangkut pautnya secara langsung dengan masalah agama tertentu. Sebab semua agama anti atau bahkan benci terhadap tindakan radikalisme tersebut.

\section{Usaha Meningkatkan Kualitas Masyarakat Islam}

Kita semua tidak mengetahui berapa lama kita akan hidup atau kapan kita akan meninggal, karena itulah kita harus memanfaatkan hidup dan kesempatan yang diberikan oleh Allah swt dengan sebaik- baiknya, dan dalam Islamlah hal ini kita dapatkan. 
Manusia dituntut untuk terus meningkatkan kualitas hidupnya. Itu dinilai sebagai langkah mencapai kebahagian hidup, baik disunia dan diahirat kelak.

Salah satu cara meningkatkan kualitas hidup yaitu dengan memperbanyak ibadah kepada Allah SWT merupakah salah satu yang wajib dilakukan agar kualitas hidup terus meningkat. Ada bebrapa teori yang perlu dilakukan oleh seseorang untuk meningkatkan kualitas hidup.

Pertama, dengan mempunyai tekad yang kuat. Tekad yang kuat harus mencapai energi 100 persen untuk melakukan perubahan kepada diri sendiri. Jika tekad tidak kuat maka cara apapun yang digunakan diyakini tidak akan mampu membawa kepada keberhasilan.

Teori kedua, seseorang harus mempunyai ilmu dengan pendidikan yang terus menerus. Karena tekad yang kuat juga akan sia-sia apabila tidak disertai ilmu.

Ketiga, seseorang yang bertekad untuk mengubah diri menjadi lebih berkualitas agar memilih teman dengan orang yang mendukung cita-cita.

Keempat, orang harus jujur dan bersedia melakukan evaluasi diri sendiri.

Kelima, harus berani menghukum diri sendiri atas kesalahan yang dilakukannya. Dan ditambah juga dengan lingkungan yang kondusif sebagai usaha bagi orang untuk meningkatkan kualitas hidupnya.

Disamping beberapa uraian konsep di atas, Ibadah dan doa yang istiqamah merupakan langkah terpenting dari semua hal yang dilakukan sebelumnya. Sebab, doa dan ibadah merupakan hubungan langsung dengan Allah. 
Kualitas keislaman adalah ukuran maksimal keislaman seorang muslim yang harus dicapai agar keislamannya mempunyai nilai di mata Allah. Akan tetapi, di dalam pencapaiannya, tidak bisa lepas dari sebuah proses, yakni pengaplikasian ibadah yang telah disyari'atkan. Sangatlah mustahil untuk penggapaian kualitas tanpa sebuah usaha disertai kuantitas.

Kualitas keislaman sangat erat hubungannya dengan kualitas keimanan serta ihsan, karena ketiga hal ini mempunyai ikatan yang fungsional, yakni saling memfungsikan satu sama lain. Jadi, tidak mungkin ada seorang muslim yang kualitas keislamannya bagus, sedangkan kualitas keimanannya tidak, atau sebaliknya. Karena kedua hal ini saling berkaitan, kalau kualitas keislamannya bagus, tetapi tanpa disertai dengan kualitas keimanannya, maka seseorang itu belum dikatakan berkualitas.

\section{Kesimpulan}

Dari uraian penjelasan yang disampaikan di atas, setidaknya dapat disimpulkan dan diambil intisarinya, bahwa tren hijrah yang terjadi saat ini merupakan usaha seseorang dalam mendekatkan diri kepada sang penciptanya. Dengan berhijrah, berarti mendekatkan diri kepada sang pencipta dan senantiasa memohon ridho-Nya. Memperbaiki diri untuk menjadi pribadi yang lebih bermanfaat untuk umat. Berhijrah yakni berpindah dengan lebih mendekatkan diri kepada Sang Khalik untuk menjadi muslim yang lebih baik. Jika kita dekat kepada-Nya kelak Allah SWT akan senantiasa memudahkan hamba-Nya dalam mengayuh rodaroda kehidupan.

Dengan berhijrah untuk mencapai ridho-Nya, Allah swt akan selalu menuntun dan menunjukkan hamba-Nya ke jalan yang benar. Seseorang yang akan naik kelas pastinya akan diberi ujian dahulu untuk menentukan layaknya atau tidaknya. Hijrah perlu keistiqomahan, namun berbagai ujian dan godaan syaithan menghampiri disaat diri ini ingin 
menjadi pribadi lebih baik. Ujian merupakan wujud cinta Allah SWT kepada hamba-Nya dan akan ada hikmah indahnya jika bersabar.

Isu radikalisme yang disematkan kepada mereka yang berhijrah adalah bagian dari tantangan dan ujian. Karena hijrah tidak bisa serta merta dikaitkan dengan radikalisme. Mereka yang berhijrah meyakini apa yang mereka lakukan sudah sesuai dengan ajaran yang sebenarnya. Kalaupun ada indikasi radikalisme itu dilakukan oleh oknum yang mengatasnamakan mereka yang sedang berhijrah.

Meningkatnya kualitas masyarakat Islam dapat dilihat banyaknya orang-orang yang menghadiri pengajian yang disi oleh para ustadz, mereka mengikuti kegiatan tersebut dengan tujuan untuk mencari dan menambah ilmu pengetahuan terutama dibidang agama.

\section{Daftar Pustaka}

Ratri, Lintang. 2011. Cadar, Media, dan Identitas Perempuan Muslim. Vol 39, No 2 (2011). (Diakses 12 Maret 2018, 20.06 WIB)

Abdullah, M. Amin. Studi Agama: Normativitas atau Historisitas, Cet. V; Jakarta: Pustaka Pelajar, 2011.

Abegebriel, A. Maftuh., dkk., Negara Tuhan: The Tematic Encylopaedia, Cet. I; Yogyakarta: SR-Ins Publishing, 2004.

Al-Faruqi, Ismail Raji., dan Lois Lamya al-Faruqi, The Cultural Atlas of Islam, New York: Macmillan Publishing Company, 1986.

Al-Mahmad, Ali Abd. Halim. Al-Da'wah al-Islamiyah Da'wah 'Alamiyah, Kairo: Majlis al-A'la li Syu'un al-Islamiyah, 1969.

Al-Qardhawi, Yusuf., dalam Irfan M. Hakim dkk., Jihad Menurut al-Qur'an dan Sunnah, Bandung: Mizan, 2010.

Amin, M. Masyhur. Dakwah Islam Dan Pesan Moral, Jakarta: Al-Amin Press, 1997

Arfina, Eka Yani. Kamus Lengkap Bahasa Indonesia Dilengkapi Dengan EYD dan Singkatan Umum, Surabaya : Tiga Dua. t.th. 
Aripudin, Acep. Sosiologi Dakwah, Bandung: Rosda Karya, 2013.

Azra, Azy Zumardi. Fenomena Fundamentalisme Dalam Islam; Survei Historis dan Doktrinal: Jurnal Ulumul Qur'an, Jakarta: No. 3 Vol. IV; t.p, 1993.

Bachtiar Effendi \& Hendro Prasetyo, Radikalisme Agama, Jakarta: PPIM IAIN Jakarta, 1998. Basit, Abdul. Wacana Dakwah Kontemporer, Yogyakarta: Pustaka Pelajar, 2006.

Luthfi, Mustafa. Melenyapkan Hantu Terorisme: Dari Dakwah Kontemporer, Jakarta Timur: Pustaka Al-Kautsar, 2008.

M. Echols, Jhon. dan Hasan Shadiliy, Kamus Bahasa Inggris Indonesia, Cet. VII; Jakarta: PT. Gramedia, 1979.

M. Noor, Hasan. Islam, Terorisme dan Agenda Global, Perta : Vol. V; No. 02/2002. Muthahhari, Murthadha. Falsafah Pergerakan Islam, Cet.III; Jakarta: Mizan, 1993. Nasution, Harun. Islam Rasional; Gagasan dan Pemikiran, Cet. VI; Jakarta Mizan, 2000.

Pranata, Rudi. An Indonesianist's View of Islamic Radicalism, Jakarta: Koran Tempo, Pebruari, 2005. Rahman, Fazlur. Gelombang Perubahan Dalam Islam: Studi Tentang Fundamentalisme Islam, Jakarta: Rajawali Press, 2000.

Simuh dkk., Islam dan Hegemoni Sosial, Cet. II; Jakarta: Media Citra, 2002. Taher, Tarmizi. dkk., Radikalisme Agama, Jakarta: PPIM IAIN, t.th.

Turmudi, Endang., (ed.), Islam dan Radikalisme di Indonesia, Jakarta: LIPI Press, 2005.

W. Arnold, Thomas. The Preaching of Islam, A History of The Propagation of The Muslim Faith, Cet. II; Delhi: Low Price Publications, 1995.

Murthadha Muthahhari, Falsafah Pergerakan Islam, cet. III: Jakarta: Mizan, 1993

Tarmizi Taher, dkk., Radikalisme Agama, Jakarta: PPIM IAIN Jakarta, 1998 